INTERNATIONAL BULLETIN

$O F$

BACTERIOLOGICAL NOMENCLATURE

AND

T AXONOMY

Volume 11

July 15, 1961

No. 3

\title{
COMMENTS ON THE NOMENCLATURE \\ OF THE CAUSATIVE AGENT OF TULAREMIA
}

Cornelius B. Philip and Cora R. Owen

U.S. Department of Health, Education and Welfare, Public Health Service, National Institutes of Health, National Institute of Allergy and Infectious Diseases, Rocky Mountain Laboratory, Hamilton, Montana

SUMMARY: The organism causing tularemia was named Bacterium tularense by McCoy and Chapin in 1912 . It has been placed in several bacterial genera in recent years. It is termed Pasteurella tularensis ( $\mathrm{McC}$ coy and Chapin) Bergey et a 1 . in the $7 \mathrm{th}(1957)$ edition of Bergey's $\bar{M}$ anual of Determinative Bacteriology. This study confirms the designation of this organism as the type species of the genus Francisella Dorofeev 1947 with the species name Francis Coy and Chapin) Dorofeev I947.

For some years, the bacterial organism causing tularemia, originally named Bacterium tularense in 1912 by McCoy and Chapin, has had an uneasy and often criticized systematic assignment to the genus Pasteurella Trevisan 1887, in which it has been included in the last edition of Bergey's Manual of Determinative Bacteriology (Breed and collaborators, 1957) as Pasteurella tularensis (McCoy and Chapin, 1912) Bergey et al., 1923.

Olsuf'ev et al. (1959) have recently stated their opinion that Dorofeev( $\overline{19} 47$ ) was correct in erecting the genus Francisella to contain this organism. The former also proposed two geographic varieties based on biological strain differences which are not pertinent to this discussion.

In a later description of the etiologic agent, Olsuf'ev and Rudnev (1960) correctly point out that Dorofeev's subsequent (Page 67) 
proposal (1956) to substitute Tularecella as the preferred generic assignment was invalid under the international rules. Since Francisella Dorofeev, 1947, was validly published, the author cannot arbitrarily reject the name (for example, by invoking Rule 12c) to propose another presumably more suitable name (Tularecella).

Three questions arise in deciding nomenclatural assignment of this species, since it is accepted as not belonging in Bacterium sens. str.: 1) What is the type species of the genus Pasteurella; 2 ) is tularensis congeneric with it; and if not, 3) is Francisella the first availabe genus to which the species can be properly assigned?

No doubt the original description of a "plague-like organism causing disease in rodents, "in an area affected by true plague caused by $\underline{P}$. pestis (Lehmann and Neumann, 1896) Holland 1920, has contributed to attempts at maintenance of tularensis in the same generic assemblage, as has. also the characteristic of bipolar staining, common to several species as now grouped.

In answer to question 1, Trevisan first erected "somewhat tentatively" (1885) the genus Octopsis with $\mathcal{O}$. choleraegallinarum (the cause of fowl cholera, possibly in reference to Micrococcus cholerae-gallinarum Zopf 1885) as the first of five included species. Two years later Trevisan (1887) abandoned this genus in favor of the new name, Pasteurella, which was validly published to contain the only associated species $\underline{P}$. cholerae-gallinarum. Because of this, the International Judicial Commission in Opinion 13 (1954, Internat. Bull. Bact. Nomen. Tax., 4: 153) placed Octopsis in the list of rejected generic names while Pasteurella was placed in the list of conserved generic names. Buchanan and Buchanan (1938) had included this organism and $\underline{P}$. tularensis in their discussion of Pasteurella.

Since Pasteurella is monobasic for $P$. cholerae-gallinarum (Zopf) Trevisan, the assignment of $\mathrm{P}$. "multocida (Leh$\overline{\operatorname{man}}$ and Neumann, 1899) Rosenbusch and Merchant 1939"*

\footnotetext{
* Actually Rosenbusch and Merchant (1939, p. 69) ascribe the typical agent to the binary combination "Pasteurella multocida, Kitt, 1885, n. comb."! But Kitt's original report (1885) provides neither a valid, new binary name for this bacterial agent nor the inadmissible ternary one, Bacterium bipolare multocidum, credited to him. P. multicoda
} 
in the Bergey system as type is valid only in the sense that the latter is accepted as an objective synonym of the former, which it appears to be. Nor can the type be either "P. avicida [Prévot]" or "Pasteurella aviseptica [Top. and Wilson]" cited by Hauduroy et al. (1953). Hughes (1930) includes $\underline{P}$. cholerae gallinarum [sic] as one of 5 synonyms of the later P. avicida, while Quortrup et al. (1946) discussed variants of the species.

On the basis of special growth requirements on enriched media, the tularemia agent does not fit the restrictive characters of the other species, including the type, now assigned to Pasteurella. This answers in the negative question 2 about congeneracy.

It is stated in standard texts that $\underline{P}$. tularensis does not grow anaerobically, which has been confirmed in recent experiments by us (unpublished data) with old laboratory-adapted and recently isolated strains. This is not a criticalcriterion for maintaining $\underline{P}$. tularensis in the genus Pasteurella, because many authorities ignore this characteristic and still consider that $P$. tularensis is not properly grouped in the assemblage of species under Pasteurella, for example, Hagan and Bruner (1951, p. 236).

Two other genera have been synonymized under Pasteurella, namely Coccobacillus Gamaleia 1888 and Eucystia Enderlein 1917. Gamaleiä described "the Coccobacillus with specific designation avicidus" (transl.) for the "avian cholera bacteria" which caused "avian septicaemia, "based on isolates from pigeons. These isolates were related immunologically to strains obtained from the Pasteur Institute. Coccobacillus appears to have been validly published at that time, but the synonymy of the agent under Pasteurella would seem to be correct and hence would not apply to $\underline{P}$. tularensis.

Eucystia was apparently validly published, even though under a family Bacteriidae (with improper zoological ending) in a key with only four dichotomically arranged characters, and despite the fact that the designated type species, $E$. pestis, was wrongly ascribed to Yersin 1894 who described but did not name the plague organism. Whether this species

therefore, was proposed and characterized (p. 85) by the former authors, though they attributed it gratuitiously to Kitt in the genus Bacterium. This name cannot supplant the above, original legitimate type species for the genus Pasteurella. 
is assignable to Pasteurella, as considered by Buchanan and Buchanan (1938), is not within the province of this discussion, but the name Eucystia will come into considerations of priority in connection with Pesticella Dorofeev 1947, described for the same agent. Even if the concept of Pasteurella is refined to include $\underline{P}$. pestis in a subgenus, Eucystia, such restriction would still relegate $P$. tularensis to adifferent subgenus on biological grounds.

Some authors have assigned $P$. tularensis to the genus Brucella but this has not been widely accepted, and again the agent is excluded on its biological properties. For similar reasons, the agent cannot be included under Coccobacterium Klinger 1912 (preoccupied by Schmidt and Weis) as

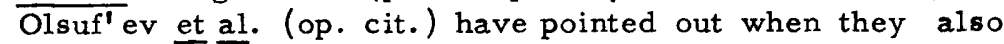
cite another name, Cystinophilus, which was verbally and not validly proposed by Elbert in 1939.

In view of the need for revised generic assignment of $\underline{P}$. tularensis, it appears that Olsuf'ev and his colleagues are correct in asserting that Francisella Dorofeev 1947 is the first available restrictive generic name. Valid publication of this genus was verified in a copy of the reference supplied to R.E. Buchanan by Professur Olsuf'evin which the binary combination in Latin, "Francisella tularense McCoy and Chapin 1910" was designated type species. The proper type species reference is, therefore, Francisella tularensis (McCoy and Chapin) Dorofeev. The name, Francisella, is equally available should subgeneric treatment ultimately be proposed on taxonomic grounds.

Since cultures of the original isolater are no longer available it will be difficult, if desirable, to select one of the present-day isolates as a neotype culture in view of the now well-known variation in biological properties.

Olsuf'ev and Rudnev proposed that Francisella should properly be placed in the latest Bergey system between the genera Brucella and Pasteurella in the family Brucellaceae of the order Eubacteriales. We agree with this and suggest the following revision in the dichotomous key to the Brucellaceae:

c. Attacks carbohydrates

d. Grows on ordinary media. . Genus Pasteurella dd. Grow only on special media. . Genus Francisella

cc. Carbohydrates not attacked. . . Genus Brucella 


\section{BIBLIOGRAPHY}

Bollinger, O. 1885. Zur Aetiologie des Milzbrandes. Sitz. Gesell. Morph. u. Physiol., München. 1: $21-26$.

Breed, R. L. and collaborators. 1957. Genús Pasteurella in Bergey's Manual of Determinative Bacteriology. Williams and Wilkins, Baltimore. 7th ed. pp. 395-402.

Buchanan, R.E. and E.D. Buchanan. 1938. Bacteriology. MacMillan Co. 4th ed. 548 pp.

Dorofeev, K.A. 1947. On classification of tularemic bacteriae. Symposium of Research Works of Inst. Epidem. Mikrobiol. in Chita. 1: 177-178.

- 1956. Tularemia (tularetsellez) in animals. Avtoref. diss. Leningrad. (cited by Olsuf'ev, 1960).

Enderlein, G. 1917. Ein neues Bakteriensystem auf vergleichend morphologischer Grundlage. (Bakteriologische Studien IV). Gesellsch. Naturforsch. Freunde zu Berlin, Sitzungsberichte. pp. 309-319.

Gamaleiă, N. 1888. Zur aetiologie der Hünercholera nebst einigen Bermerkungen über die Schutzimpfungsfrage. Centrl. f. Bakt., 4: 161-168.

Hagan, W.A. and D. $\vec{W}$. Bruner. 1951. The Infectious Diseases of Domestic Animals. 2nd Edition, Comstock Publishing Company, Inc., Ithaca, New York. 920 pp.

Hauduroy, P., Ehringer, Guillot, G., Magrou, Prévot, A. R., Rosset and Urbain. 1953. Dictionnaire des bactéries pathogènes pour $1^{t}$ homme, les animaux et les plantes. 2nd ed. Masson, Paris. 692 pp.

Hughes, T.P. 1930. The epidemiology of fowl cholera. II. Biological properties of $\underline{\underline{P}}$. avicida. J. Exp. Med., 51: $225-233$.

Kitt, T. 1885. Ueber eine experimentelle, der Rinderseuche (Bollinger) ăhnliche Infectionskrankheit. Sitz. Gesell. Morph. u. Physiol., München. 1: 140-168.

Klinger, P. 1912. Ueber eine neuen pathogenen Anaëroben aus menschlichem Eiter (Coccobacterium mucosum anaërobicum n. sp.). Zentralbl. Bakt. I. Abt. Orig., 62: $186-191$.

Lehman, K.B. and R. Neumann. 1899. Atlas und Grundriss der Bakteriologie und Lehrbuch der speciellen bakteriologischen Diagnostik. München. 2 Aufl., 2: 495 pp. 
McCoy; G. W. and C.W. Chapin. 1912. Bacterium tularense the cause of a plague-like disease in rodents. Pub. Health Bull. No. 53: 17-23.

Olsuf ev. N.G., O.S. Emelyanova and T.N. Dunayeva. 1959. Comparative study of strains of $\underline{B}$. tularensa in the Old and New World and their taxonomy. J. Hyg., Epidem., Microbiol., and Immunola, 3: 138-149. and Rudnev, G.P. (editors). 1960. Tularemia.

\footnotetext{
Medgiz, Moscow. 459 pp.
}

Quortrup, E.R., F.B., Queen and L.J. Merovka. 1946. An outbreak of pasteurellosis in wild ducks. J. Am. Vet. Med. Assoc., 108: 94-100.

Rosenbusch, C.T. and I. A. Merchant. 1939. A study of the hemorrhagic septicemia Pasteurellae. J. Bact., 37: 69-89.

Trevisan de Saint Leon, V. 1885. Caratteri di alcuni nuovi generi di Batteriace. Atti della Academia FisioMedico-Statiscain Milano, Ser. 4, 3: 92-107. - 1887. Sul Micrococco della rabbia e sulla possibilita di riconescere durante il periodo $\mathrm{d}^{2}$ incubazione, etc. Rendiconti Reale Instituto Lombardo di Scienze e Lettere, Series II, 20: 87-105.

Zopf, W. 1875. Die Spaltpilze. Nach dem neuesten Standpunkte bearbeitet. Breslaw 3 Aufl., 127 pp. 